\title{
Research Article \\ Effect of Fungicide Applications on Grain Sorghum (Sorghum bicolor L.) Growth and Yield
}

\author{
Dan D. Fromme, ${ }^{1}$ Trey Price, ${ }^{2}$ Josh Lofton, ${ }^{3}$ Tom Isakeit, ${ }^{4}$ Ronnie Schnell, ${ }^{5}$ Syam Dodla, ${ }^{6}$ \\ Daniel Stephenson, ${ }^{1}$ W. James Grichar, ${ }^{7}$ and Keith Shannon ${ }^{1}$
}

\author{
${ }^{1}$ LSU AgCenter, 8208 Tom Bowman Drive, Alexandria, LA 71302, USA \\ ${ }^{2}$ LSU AgCenter, 212A Macon Ridge Road, Winnsboro, LA 71295, USA \\ ${ }^{3}$ Oklahoma State University, Stillwater, OK 74078, USA \\ ${ }^{4}$ Department of Plant Pathology and Microbiology, Texas A\&M University, College Station, TX 77843, USA \\ ${ }^{5}$ Department of Soil and Crop Science, Texas A\&M University, College Station, TX 77843, USA \\ ${ }^{6}$ LSU AgCenter, 262 Research Station Drive, Bossier City, LA 71112, USA \\ ${ }^{7}$ Texas A\&M AgriLife Research and Extension Center, Corpus Christi, TX 78406, USA
}

Correspondence should be addressed to W. James Grichar; w-grichar@tamu.edu

Received 27 September 2016; Accepted 1 February 2017; Published 21 February 2017

Academic Editor: Kent Burkey

Copyright (c) 2017 Dan D. Fromme et al. This is an open access article distributed under the Creative Commons Attribution License, which permits unrestricted use, distribution, and reproduction in any medium, provided the original work is properly cited.

Field studies were conducted in the upper Texas Gulf Coast and in central Louisiana during the 2013 through 2015 growing seasons to evaluate the effects of fungicides on grain sorghum growth and development when disease pressure was low or nonexistent. Azoxystrobin and flutriafol at $1.0 \mathrm{~L} / \mathrm{ha}$ and pyraclostrobin at $0.78 \mathrm{~L} / \mathrm{ha}$ were applied to the plants of two grain sorghum hybrids (DKS 54-00, DKS 53-67) at 25\% bloom and compared with the nontreated check for leaf chlorophyll content, leaf temperature, and plant lodging during the growing season as well as grain mold, test weight, yield, and nitrogen and protein content of the harvested grain. The application of a fungicide had no effect on any of the variables tested with grain sorghum hybrid responses noted. DKS 53-67 produced higher yield, greater test weight, higher percent protein, and $\mathrm{N}$ than DKS 54-00. Results of this study indicate that the application of a fungicide when little or no disease is present does not promote overall plant health or increase yield.

\section{Introduction}

Fungicides are a vital solution to the effective control of plant diseases which are estimated to cause yield reductions of almost $20 \%$ in major food and cash crops worldwide [1]. In the past few years, there has been increased controversy over whether fungicides should be applied to field crops in the absence of disease $[2,3]$. Despite a lack of scientific evidence supporting "plant health," the US Environmental Protection Agency has granted a supplemental label for the use of pyraclostrobin (Headline ${ }^{\circledR}$, BASF Corp., Research Triangle Park, NC 27709) fungicide for "plant health" [4], which may be misleading. Fungicides have been shown to have effects on crop growth and physiology by various disruptions such as growth reduction, perturbation in the development of reproductive organs, alteration of nitrogen, and/or carbon metabolism leading to a lower nutrient availability for plant growth. The sensitivity of some plant species may depend on the developmental stage (e.g., more sensitive to the treatments at young stages or during critical events such as reproduction) or the type of pesticides used [1].

Grain sorghum in the US is primarily grown on dryland hectares in the "sorghum belt" which stretches from South Dakota to southern Texas. In 2015, grain sorghum was planted on 3.4 million hectares with an average yield of $4409 \mathrm{~kg} / \mathrm{ha}$ [5]. Fungicides have been used in grain sorghum to manage a number of foliar diseases in the southern US including anthracnose (Colletotrichum graminicola [Ces.] G. W. Wilson [syn. C. sublineolum P. Henn., in Kabat. \& Bubak]), gray leaf spot (Cercospora sorghi Ellis \& Everh.), target leaf spot (Bipolaris sorghicola [Lefebvre \& Sherwin] Alcorn), and zonate leaf spot (Gloeocercospora sorghi D. Bain \& Edgerton 
ex Deighton) [6, 7]. Older fungicides used to manage grain sorghum diseases had multisite modes of action and were contact fungicides which remain on the leaf surface and were easily washed off [8]. With improved chemistry, systemic fungicides are now available and these types of fungicides are absorbed by the leaves and move within the treated plant [8]. Systemic fungicides allow growers to properly manage grain sorghum diseases now more than ever before.

The quinone outside inhibitor (QoI) class of fungicides, commonly referred to as strobilurins, are a relatively newer class of fungicides that have been commercially available in Europe and the US since the mid-to-late 1990s [9]. This class of fungicides disrupt electron transport in the mitochondria and diminish adenosine triphosphate (ATP) production [9], which effectively prevents spore germination and reduces mycelial growth in ascomycetes, basidiomycetes, deuteromycetes, and oomycetes $[10,11]$. This mode of action is also purported to induce nonfungicidal, physiological changes within the plant, such as greater chlorophyll retention, increased water and nitrogen use efficiency, and delayed senescence [12-14].

Three of the newer fungicides labeled for use in grain sorghum are azoxystrobin, flutriafol, and pyraclostrobin. Azoxystrobin and pyraclostrobin are strobilurin-type fungicides that have shown activity against many different fungal pathogens in soybean (Glycine max L.), peanut (Arachis hypogaea L.), and various other crops [15-18]. Pyraclostrobin is rapidly absorbed by leaf tissue and has demonstrated translaminar movement through layers of the leaf; however, the material is not redistributed throughout the plant like a true systemic fungicide $[9,19]$. Selected rates of pyraclostrobin have superior activity against the peanut leafspots, caused by Cercospora arachidicola and C. personatum, as well as soil-borne diseases such as southern stem rot (Sclerotium rolfsii Sacc.) [20].

Azoxystrobin is reported to have activity against both Rhizoctonia solani and Pythium spp. [21-23]. Uptake of azoxystrobin into leaves is a gradual process; for example, 1 to $3 \%$ of the applied material is absorbed into a grape leaf within $24 \mathrm{hr}$ of foliar application [9]. Strobilurins like azoxystrobin move across the leaf surface and into the waxy cuticle of the leaf (locally systemic) and may even move into the cuticle of the underside of the leaf (translaminar activity) [24]. Some of the material also may move into the xylem and be transported upwards; however, the plant does not transport much, if any, fungicide down to the roots [9].

Flutriafol is a systemic demethylation inhibitor (DMI) fungicide that is labeled as a curative or a preventative treatment in grain sorghum [25]. The material inhibits the specific enzyme, C14-demethylase, a fungal cytochrome P450, which plays a role in sterol production [25]. Sterols are a requirement for fungal membrane structure and function and are essential for the development of functional cell walls [24, 25]. It was first registered by the EPA for use on apples (Malus domestica Borkh) and soybeans in 2010. In 2012, the fungicide was approved for use on corn (Zea mays L.) [25]. Recently, flutriafol received approval for use on cotton (Gossypium hirsutum L.) to manage Phymatotrichopsis root rot of cotton [26].
There is very limited information available on the response of grain sorghum to fungicides, especially to document whether a fungicide application causes nonfungicidal physiological changes and yield increases in years of little disease development. However, growers continue to inquire about the use of fungicides in grain sorghum production and their value. Therefore, the objectives of this research were (1) to assess the effects of fungicide applications applied to grain sorghum on seed yield when foliar disease incidence was low or nonexistent and (2) to determine if a fungicide application can be associated with nonfungicidal physiological changes and yield components or grain composition under field conditions.

\section{Materials and Methods}

2.1. Research Sites. Grain sorghum fungicide studies were conducted in 2013 along the upper Texas Gulf Coast near Wharton on the Michael Beard Farm (29.296036N, 96.221369W) and in 2014 (31.17540N, 92.40517W) and 2015 (31.17302N, 92.40922W) in central Louisiana at the Rapides Parish-Dean Lee Research and Extension Center near Alexandria, Louisiana. Cotton was planted prior to grain sorghum at the two locations in all three years. Soil type at the Wharton location was a Lake Charles clay (fine, smectitic, hyperthermic, Typic Hapluderts) with a $\mathrm{pH}$ of 6.5 while soils at both Alexandria locations was a Coushatta silt loam (fine-silty, mixed, superactive, thermic Fluventic EutrudeptsCoushatta silt loam) with a $\mathrm{pH}$ range of 6.5 to 6.8. Conventional tillage systems were used at both locations and both sites were maintained under rainfed conditions. Fertilizer at the Wharton location included $125 \mathrm{~kg} / \mathrm{ha}$ of $\mathrm{N}, 44 \mathrm{~kg} / \mathrm{ha}$ of $\mathrm{P}, 17 \mathrm{~kg} / \mathrm{ha}$ of $\mathrm{K}$, and $8 \mathrm{~kg} / \mathrm{ha}$ of $\mathrm{Zn}$ while at Alexandria $168 \mathrm{~kg} / \mathrm{ha}$ of $\mathrm{N}, 34 \mathrm{~kg} / \mathrm{ha}$ of $\mathrm{P}, 67 \mathrm{~kg} / \mathrm{ha}$ of $\mathrm{K}$, and $2 \mathrm{~kg} / \mathrm{ha}$ of $\mathrm{Zn}$ were applied in both years. Plots were maintained weed-free at the Wharton County location throughout the growing season using a preemergence (PRE) application of a premix of dimethenamid P plus atrazine (Guardsman $\mathrm{Max}^{\circledR}$, BASF Corporation, Research Triangle Park, NC 27709) at 3.2 L/ha plus dimethenamid (Outlook ${ }^{\circledR}$, BASF Corporation, Research Triangle Park, NC 27709) at $0.13 \mathrm{~kg} / \mathrm{ha}$ while at the Alexandria location, $S$-metolachlor (Medal II ${ }^{\circledR}$, Syngenta Crop Protection, Greensboro, NC 27419) at $1.2 \mathrm{~L} /$ ha plus atrazine at $3.55 \mathrm{~L} /$ ha were applied PRE. No insecticides were applied at the Wharton location; however, at Alexandria in 2014, two applications of sulfoxaflor (Transform ${ }^{\circledR}$, Dow AgroSciences, Indianapolis, IN 46268) were applied at $110 \mathrm{ml} / \mathrm{ha}$. In 2015 , sulfoxaflor was applied at $73 \mathrm{ml} / \mathrm{ha}$ followed by flupyradifurone (Sivanto, Bayer CropSciences LP, Research Triangle Park, NC 27709) at $365 \mathrm{ml} / \mathrm{ha}$. In both years, these insecticides were applied to control the sugarcane aphid (Melanaphis sacchari L.). Prior to harvest, glyphosate (Roundup WeatherMaxx ${ }^{\circledR}$, Monsanto Co., St. Louis, MO 63167 ) at $2.24 \mathrm{~L} /$ ha was applied at $30 \%$ physiological maturity to hasten grain drydown and aid in plant desiccation for ease of harvest. Plots were hand harvested and mechanically threshed at Wharton (July 9, 2013) while a small plot combine was used at the Alexandria location (August 18, 2014; August $5,2015)$. Final yields were adjusted to $14 \%$ moisture. 
TABLE 1: Rainfall amounts during the 2013 through 2015 growing season at each test location.

\begin{tabular}{|c|c|c|c|c|c|}
\hline \multirow{3}{*}{ Month } & \multicolumn{2}{|c|}{ Wharton, Texas (2013) } & \multicolumn{3}{|c|}{ Alexandria, Louisiana } \\
\hline & Monthly & $30 \mathrm{yr}$ average & 2014 & 2015 & $30 \mathrm{yr}$ average \\
\hline & & & $\mathrm{Mm}$ & & \\
\hline March & 12.7 & 80.8 & 49.0 & 180.9 & 131.9 \\
\hline April & 116.8 & 83.8 & 96.5 & 229.6 & 116.1 \\
\hline May & 66.0 & 119.4 & 110.5 & 160.8 & 119.9 \\
\hline June & 20.3 & 126.5 & 111.0 & 137.9 & 136.9 \\
\hline July & 33.0 & 83.1 & 132.1 & 46.5 & 112.0 \\
\hline August & 38.1 & 74.9 & 215.4 & 41.7 & 103.9 \\
\hline Total & 286.9 & 568.5 & 714.5 & 797.4 & 720.7 \\
\hline
\end{tabular}

2.2. Grain Sorghum Hybrids and Fungicide Treatments. Grain sorghum hybrids (DKS 54-00 and DKS 53-67) were those commonly used in production fields in south-central Texas and central Louisiana. Grain sorghum seed was planted at the rate of $198,000 \mathrm{seed} / \mathrm{ha}$ with either a 2- or 4-row cone planter. Planting dates were March 8, 2013, at the Wharton County location and April 4, 2014, and April 1, 2015, at the Alexandria location. Treatments consisted of a factorial arrangement of the two grain sorghum hybrids with four fungicide treatments (nontreated, azoxystrobin and flutriafol at $1.0 \mathrm{~L} /$ ha and pyraclostrobin at $0.78 \mathrm{~L} / \mathrm{ha}$ ). Only azoxystrobin included Agridex (Helena Chemical Co., 6075 Poplar Ave., Memphis, TN 38119), a crop oil concentrate, at $1.0 \% \mathrm{v} / \mathrm{v}$. Each study was replicated four times.

2.3. Plots and Rainfall. Individual plots consisted of four rows (102 cm centers at Wharton and $97 \mathrm{~cm}$ centers at Alexandria) by $15.2 \mathrm{~m}$ long with 4 reps at each location. The four rows of each plot in each study were sprayed with fungicide and data (including yield) were collected from the middle two rows. Rainfall for the upper Texas Gulf Coast (Wharton, TX) in 2013 can be best described as well below average for all months of the growing season with the exception of April (Table 1). Seasonal rainfall at the Alexandria location in 2014 can be described as below average during the early part of the growing season (March through April) but near or above average during the rest of the growing season. The 2015 growing season can be described as above normal rainfall early (March through June) but below average during July and August (Table 1).

2.4. Fungicide Application. At the Wharton County location, fungicides were applied with a Lee ${ }^{\circledR}$ Spider sprayer equipped with one 8003 XR flat fan nozzle (TeeJet Spraying Systems Co., Wheaton, IL 60188) per row, while at Alexandria, fungicides were applied with a $\mathrm{CO}_{2}$-propellant backpack sprayer equipped with one 8001 flat fan spray nozzle (TeeJet Spraying Systems Co., Wheaton, IL 60188) per row. At all locations, fungicides were applied in $140 \mathrm{~L}$ of water/ha at a pressure of $315 \mathrm{kPa}$ at the Wharton County location or $504 \mathrm{kPa}$ at Alexandria. Fungicides were applied at 25\% bloom at each location which was 84 (May 31), 80 (June 23), and 83 (June 23) days after planting (DAP) in 2013, 2014, and 2015, respectively.
2.5. Leaf Chlorophyll Concentration. Grain sorghum leaf chlorophyll concentrations were determined using a SPAD 502 chlorophyll meter (Konica Minolta; Ramsey, NJ 07446). Readings were taken on the flag leaf between the mid-vein and leaf margin and reported values are the average of readings collected from ten plants in the center two rows of each plot at solar noon. Measurements were taken on a weekly basis beginning the day before fungicide application until black layer was reached.

2.6. Leaf Temperature. Leaf temperature readings were taken using a Raytek ST Pro temperature gun (Raytek Corp.; Santa Cruz, CA 95061). Readings were taken at the same location and time as leaf chlorophyll measurements on ten plants and reported values are the average of the readings.

2.7. Seed $N$ and Protein, Stalk Lodging, and Grain Mold Ratings. Seed N and protein were determined by the high temperature combustion process [27-29] (Texas A\&M Soil, Water and Forage Testing Lab; College Station, TX 77843). Stalk lodging data was collected the day prior to harvest and was calculated based on the total number of plants lodged per plot divided by the total number of plants per plot. Grain mold was determined on a scale of 1 to 5 with $1=$ seed bright with no mold or discoloration and $5=$ seed covered entirely with mold and was deteriorated and looked dead.

2.8. Data Analysis. The treatment design was a factorial arrangement using a randomized complete block design with fungicides and grain sorghum hybrids as factors. An analysis of variance was performed using the ANOVA procedure for SAS (SAS Institute, 1998, SAS user's guide, SAS Institute, Cary, NC) to evaluate the significance of fungicide and grain sorghum hybrid on overall plant health which included leaf chlorophyll concentration and temperature, plant lodging, grain mold, grain test weight and yield, and percent nitrogen and protein in the grain. The Fishers Protected LSD at the 0.05 level of probability was used for separation of mean differences.

\section{Results and Discussion}

Across years at both locations, very few or no foliar disease symptoms were present among the two grain sorghum 
hybrids (data not shown) even though rainfall was near normal or above normal at Alexandria (Table 1). Also, across all variables tested, differences between the untreated check and any fungicide treatment were noted only in 2015 and there was not a fungicide by hybrid interaction for any variables tested (data not shown). Grain sorghum hybrid response to the several test variables was noted (Table 2). This indicates that grain sorghum was only slightly affected by the application of a fungicide. This is contrary to industry advertisements claiming otherwise.

3.1. Leaf Chlorophyll Content. The effect of fungicide was only noted in 2015 at 13 weeks after planting when the untreated and flutriafol treatments produced the highest readings and pyraclostrobinthe lowest (Table 2). Also, hybrid response was noted in 2013 at 13 weeks after planting when DKS 53-67 resulted in higher readings than DKS 54-00 and also in 2013 and 2014 at 15 weeks after planting when different results were noted. In 2013, DKS 53-67 resulted in the highest reading while in 2014 the opposite was found. Henry et al. [30] noted no difference in leaf chlorophyll readings with nine different fungicides on soybean.

3.2. Leaf Temperature Readings. Only in 2015 at week 11 was a response noted with fungicides while hybrid differences were noted in 2013 and 2014 (Table 2). In 2015 at week 11, leaf temperature was the greatest with pyraclostrobin while azoxystrobin produced the lowest temperature. Hybrid differences in leaf temperature were noted in 2013 and 2014 but not 2015 (Table 2). Results were inconsistent in both years as in some instances DKS 53-67 produced higher leaf temperatures and in other instances DKS 54-00 produced higher temperatures.

3.3. Test Weight. Only a hybrid response was noted in 2013 and 2014 with DKS 53-67 producing higher test weight than DKS 54-00 in both years.

3.4. Yield. A response to fungicides was noted only in 2015 (Table 2). Flutriafol produced the highest yield and azoxystrobin and pyraclostrobin the lowest. However, no fungicide treatment was different from the untreated check. In 2013 and 2014, DKS 53-67 outyielded DKS 54-00. Swoboda and Pedersen [31] noted, in a 2-year study on soybean, that fungicides had no effect on yield. Grichar [15] noted that the use of fungicides on soybean along the upper Texas Gulf Coast under little or no disease pressure resulted in few increases in yield and subsequent increases in net returns. In several instances, the use of fungicides resulted in a decrease in net returns, especially in a year with below normal rainfall. However, Paul et al. [32] reported that, in corn, generally the mean yield was higher in plots treated with fungicides than in the nontreated plots.

3.5. Protein Content. Only a hybrid response was noted with DKS 53-67 having a higher protein content than DKS 54-00 in both 2013 and 2015 with no differences noted in 2014 (Table 2). Swoboda and Pedersen [31] noted no differences in protein content among fungicide treatments in soybean.
3.6. Seed N Content. As was seen with protein content, only a hybrid response was noted. In all three years, DKS 53-67 had a higher N content than DKS 54-00.

3.7. Grain Mold. In 2015, the untreated check resulted in a higher grain mold rating than any of the fungicide treatments while in 2014 a hybrid difference was noted as DKS 54-00 had a higher rating than DKS 53-67 (Table 2).

3.8. Lodging. No lodging was noted with any hybrid or fungicide treatment (data not shown).

The results from the various variables tested in this study fail to show a consistent overall improvement in plant health and other advantages to using a fungicide under low disease pressure. Other studies in various crops have also failed to indicate that the application of a fungicide would improve overall plant health and result in an increase in yield. The prophylactic use of fungicides may confer risks beyond economic losses. QoI or strobilurin fungicides are classified by the Fungicide Resistance Action Committee (FRAC) as highrisk for resistance development [30]. Over 40 pathogens have been reported as being resistant to QoI fungicides worldwide [33]. Recently, isolates of Cercospora sojina Hara on soybean were confirmed as resistant to strobilurin fungicides even though these fungicides have only been widely used in soybean for a few years [34]. Swoboda and Pedersen [31] concluded that under the low disease incidence noted in Iowa a low probability exists that the use of a fungicide on soybean would increase yield by mechanisms other than disease control. Wrather et al. [35] reported that foliar applications of azoxystrobin may be useful for the management of some foliar soybean diseases, but azoxystrobin may increase the percent of Phomopsis spp. seed infection. It was felt that azoxystrobin may interfere with the plant's natural defense mechanism to Phomopsis spp., or it may protect the plant from other diseases, thus extending the life of the plant so that Phomopsis spp. has more time to move from the pod into the seed. Spokas and Jacobson [36] reported no long-term negative impacts on the soil system or strawberry (Fragaria $\mathrm{x}$ ananassa) production as a consequence of strobilurin usage. In one of two years, they reported a yield boost on strawberries as a result of fungicide usage.

Paul et al. [32] stated that unless a corn crop is at risk of developing fungal disease, farmers would be smart to skip fungicide treatments that promise increased yields. They reported that fungicides used in fields where conditions were optimal for fungal diseases improved yields and paid for themselves. Some studies in wheat (Triticum aestivum) have indicated that QoI and DMI fungicides may delay senescence causing a "greening effect" by reducing oxygen in the leaves thereby protecting plants from toxic reactive oxygen species [37]. Others have hypothesized that the greening effect in wheat is a result of the inhibition of ethylene production by the QoI fungicides [13]. Other research has found no effect of the QoI or DMI fungicides on wheat senescence, biomass, or yield [38].

In conclusion, in the absence of any disease pressure, the application of a fungicide may not improve grain sorghum plant health or increase yield and may ultimately reduce net 


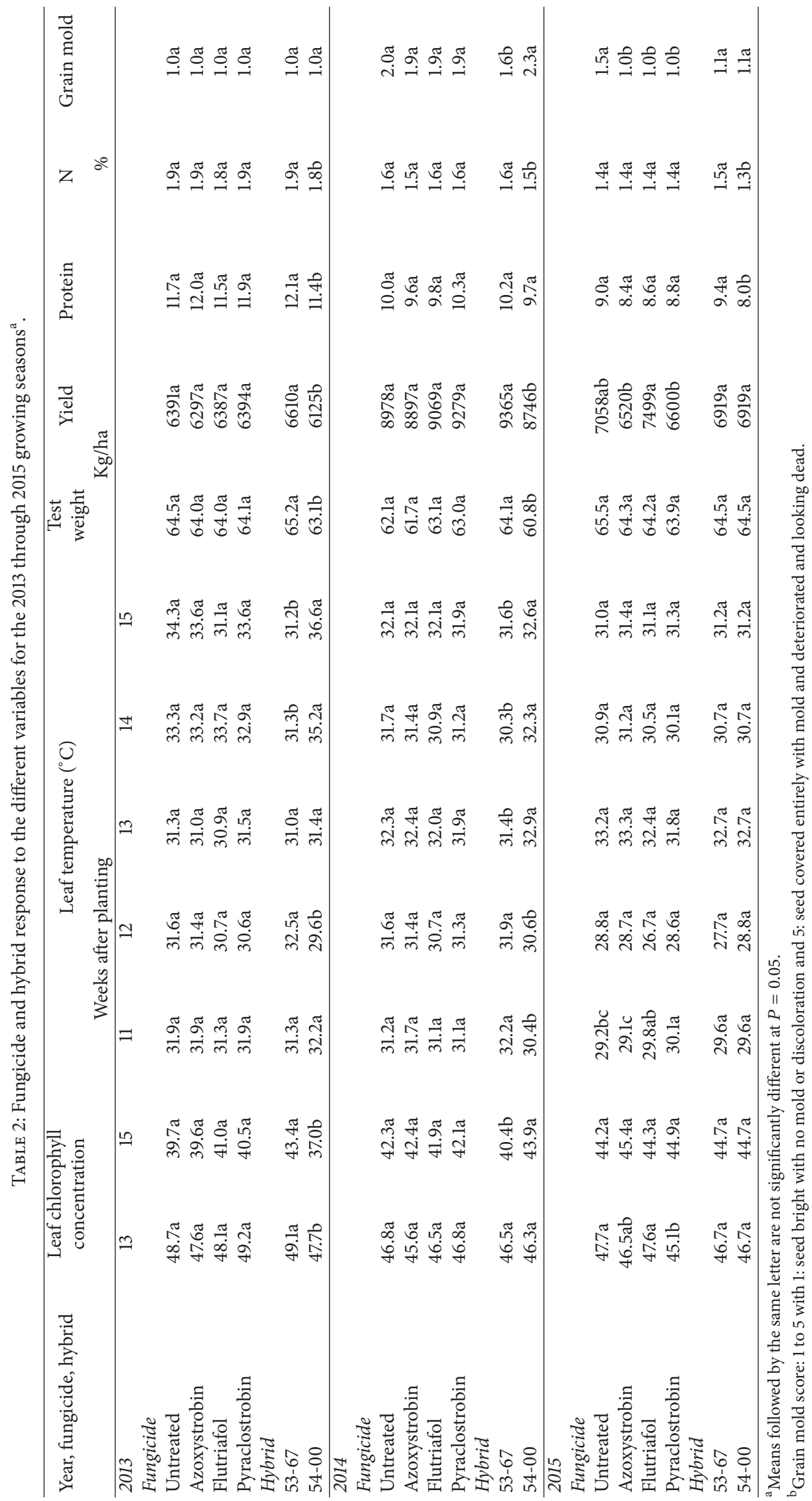


returns because of the added cost of a fungicide and application. However, if conditions are conducive to disease development, the application of a fungicide may prove beneficial.

\section{Competing Interests}

The authors declare that there is no conflict of interests regarding the publication of this manuscript.

\section{References}

[1] A.-N. Petit, F. Fontaine, P. Vatsa, C. Clément, and N. VaillantGaveau, "Fungicide impacts on photosynthesis in crop plants," Photosynthesis Research, vol. 111, no. 3, pp. 315-326, 2012.

[2] P. Vincelli and D. Hershman, "Update on fungicides for 'plant health,' Kentucky Pest News, no. 1212, 2009, http://www.uky .edu/Ag/kpn/kpn_09/pn_090915.html.

[3] D. Brown-Rytlewski and P. Vincelli, Letter from Universities Regarding the Strobilurin, Pyraclostrobin (Headline), Supplemental Label, U.S. Environmental Protection Agency, Washington, DC, USA, 2009, http://pmep.cce.cornell.edu/profiles/fungnemat/febuconazole-sulfur/pyraclostrobin/pyraclos_et_0209.pdf.

[4] Anonymous, Headline Fungicide Supplemental Label, BASF Corporation, Florham Park, NJ, USA, 2008.

[5] Anonymous, "All about sorghum," United sorghum checkoff program, http://www.sorghumcheckoff.com/all-about-sorghum.

[6] C. Hollier, "Commercial crop production field crops-rain sorghum," Louisiana Field Crops, 2015, http://www.lsuagcenter .com/NR/rdonlyres/E8519934-CB7D-4785-970A-709C01CC03B0/ 101294/10GrainSorghum2015.pdf.

[7] F. Gould and C. Gautreaux, "Odds are low for grain sorghum disease, but still scout," LSU AgCenter, 2015, http://www.lsuagcenter.com/topics/crops/soybeans/soybean_grain_promotion board_reports/odds-are-low-for-grain-sorghum-disease-but-stillscout.

[8] J. Harrington, "Foliar fungicides for soybeans increase yield potential," Plant Health Progress, 2009, http://www.plantmanagementnetwork.org/pub/php/news/2009/FoliarFungicides2/.

[9] D. W. Bartlett, J. M. Clough, J. R. Godwin, A. A. Hall, M. Hamer, and B. Parr-Dobrzanski, "The strobilurin fungicides," Pest Management Science, vol. 58, no. 7, pp. 649-662, 2002.

[10] R. Stierl, M. Merk, W. Schrof, and W. S. Butterfield, "Activity of the new BASF strobilurin fungicide, BAS 500 F, against Septoria tritici on wheat," in Proceedings of the British Crop Protection Council Conference, pp. 859-864, Brighton, UK, 2000.

[11] W. Venancio, M. Rodrigues, E. Begliomini, and N. Souza, "Physiological effects of strobilurin fungicide on plants," Ponta Grossa, vol. 9, pp. 59-68, 2003.

[12] J. Glaab and W. M. Kaiser, "Increased nitrate reductase activity in leaf tissue after application of the fungicide Kresoximmethyl," Planta, vol. 207, no. 3, pp. 442-448, 1999.

[13] K. Grossmann and G. Retzlaff, "Bioregulatory effects of the fungicidal strobilurin kresoxim-methyl in wheat (Triticum aestivum)," Pesticide Science, vol. 50, no. 1, pp. 11-20, 1997.

[14] H. Kohle, K. Grossmann, T. Jabs et al., "Physiological effects of the strobilurin fungicide F 500 on plants," in Proceedings of the Modern Fungicides and Antifungal Compounds III, Thuringia, Germany, 2002.

[15] W. J. Grichar, "Soybean (Glycine max L.) response to fungicides in the absence of disease pressure," International Journal of Agronomy, vol. 2013, Article ID 561370, 5 pages, 2013.
[16] D. Mueller, "Evaluation of foliar fungicides for management of soybean rust," Integrated Crop Management IC-498, no. 3, 2007.

[17] A. K. Culbreath, T. B. Brenneman, and R. C. Kemerait, "Management of early leaf spot of peanut with pyraclostrobin as affected by rate and spray interval," Plant Health Progress, 2002.

[18] A. K. Hagan, H. L. Campbell, K. L. Bowen, and L. Wells, "Impact of application rate and treatment interval on the efficacy of pyraclostrobin in fungicide programs for the control of early leaf spot and southern stem rot on peanut," Peanut Science, vol. 30, no. 1, pp. 27-34, 2003.

[19] R. Stierl, E. J. Butterfield, H. Koehle, and G. Lorenz, "Biological characterization of the new strobilurin fungicide BAS $500 \mathrm{~F}$," Phytopathology, vol. 90, p. S74, 2000.

[20] H. E. Portillo, R. R. Evans, J. S. Barnes, and R. E. Gold, "F500, a new broad-spectrum fungicide for control of peanut diseases," Phytopathology, vol. 91, p. S202, 2001.

[21] W. J. Grichar, B. A. Besler, and A. J. Jaks, "Use of azoxystrobin for disease control in texas peanut," Peanut Science, vol. 27, no. 2, pp. 83-87, 2000.

[22] M. Mihajlovic, E. Rekanovic, J. Hrustic et al., "In vitro and in vivo toxicity of several fungicides and Timorex gold biofungicide to Pythuim aphanidermatum," Pesticides \& Phytomedicine, vol. 28, no. 2, pp. 117-123, 2013.

[23] C. E. Windels and J. R. Brantner, "Early-season application of azoxystrobin to sugarbeet for control of Rhizoctonia solani AG 4 and AG 2-2," Journal of Sugarbeet Research, vol. 42, no. 1, pp. 1-16, 2005.

[24] H. Balba, "Review of strobilurin fungicide chemicals," Journal of Environmental Science and Health - Part B Pesticides, Food Contaminants, and Agricultural Wastes, vol. 42, no. 4, pp. 441451, 2007.

[25] Flutriafol, "New use review," 2012, http://www.mda.state.mn.us/ chemicals/pesticides/regs/ /media/Files/chemicals/reviews/nurflutriafol.ashx.

[26] T. Isakeit, "Using Topguard to control root rot: pay attention to that label," Texas Row Crops Newsletter, 2015, http://agrilife .org/texasrowcrops/2015/02/27/using-topguard-to-control-rootrot-pay-attention-to-that-label/.

[27] B. H. Sheldrick, "Test of the LECO CHN-600 determinator for soil carbon and nitrogen analysis," Canadian Journal of Soil Science, vol. 66, no. 3, pp. 543-545, 1986.

[28] R. A. Sweeney, "Generic combustion method for determination of crude protein in feeds: collaborative study," Journal of the Association of Official Analytical Chemists, vol. 72, no. 5, pp. 770-774, 1989.

[29] D. W. Nelson and L. E. Sommers, "Determination of total nitrogen in plant material," Agronomy Journal, vol. 65, no. 1, pp. 109-112, 1973.

[30] R. S. Henry, W. G. Johnson, and K. A. Wise, "The impact of a fungicide and an insecticide on soybean growth, yield, and profitability," Crop Protection, vol. 30, no. 12, pp. 1629-1634, 2011.

[31] C. Swoboda and P. Pedersen, "Effect of fungicide on soybean growth and yield," Agronomy Journal, vol. 101, no. 2, pp. 352356, 2009.

[32] P. A. Paul, L. V. Madden, C. A. Bradley et al., "Meta-analysis of yield response of hybrid field corn to foliar fungicides in the U.S. corn belt," Phytopathology, vol. 101, no. 9, pp. 1122-1132, 2011.

[33] FRAC, "List of plant pathogenic organisms resistant to disease control agents," 2011, http://www.frac.info/docs/default-source/ publications/list-of-resistant-plant-pathogens/list-of-resistantplant-pathogenic-organisms---february-2013.pdf?sfvrsn $=4$. 
[34] C. A. Bradley, "Frogeye leaf spot pathogen with reduced sensitivity to fungicides found in Tennessee soybean field," University Illinois Extension Bulletin 172, 2010.

[35] J. A. Wrather, J. G. Shannon, W. E. Stevens, D. A. Sleper, and A. P. Arelli, "Soybean cultivar and foliar fungicide effects on Phomopsis sp. seed infection," Plant Disease, vol. 88, no. 7, pp. 721-723, 2004.

[36] K. Spokas and B. Jacobson, Impacts of Strobilurin Fungicides on Yield and Soil Microbial Processes for Minnesota Strawberry Production, Minnesota Fruit and Vegetable Growers Association, St. Cloud, Minn, USA, 2010.

[37] Y.-X. Wu and A. Von Tiedemann, "Physiological effects of azoxystrobin and epoxiconazole on senescence and the oxidative status of wheat," Pesticide Biochemistry and Physiology, vol. 71, no. 1, pp. 1-10, 2001.

[38] J. R. Bertelsen, E. De Neergaard, and V. Smedegaard-Petersen, "Fungicidal effects of azoxystrobin and epoxiconazole on phyllosphere fungi, senescence and yield of winter wheat," Plant Pathology, vol. 50, no. 2, pp. 190-205, 2001. 


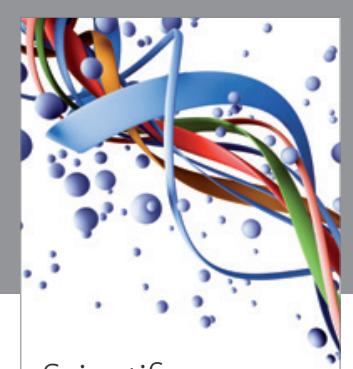

Scientifica
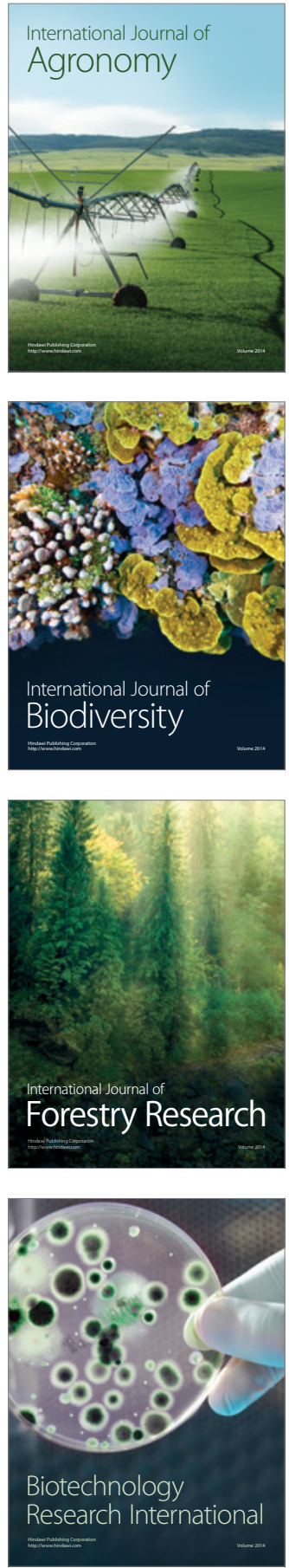
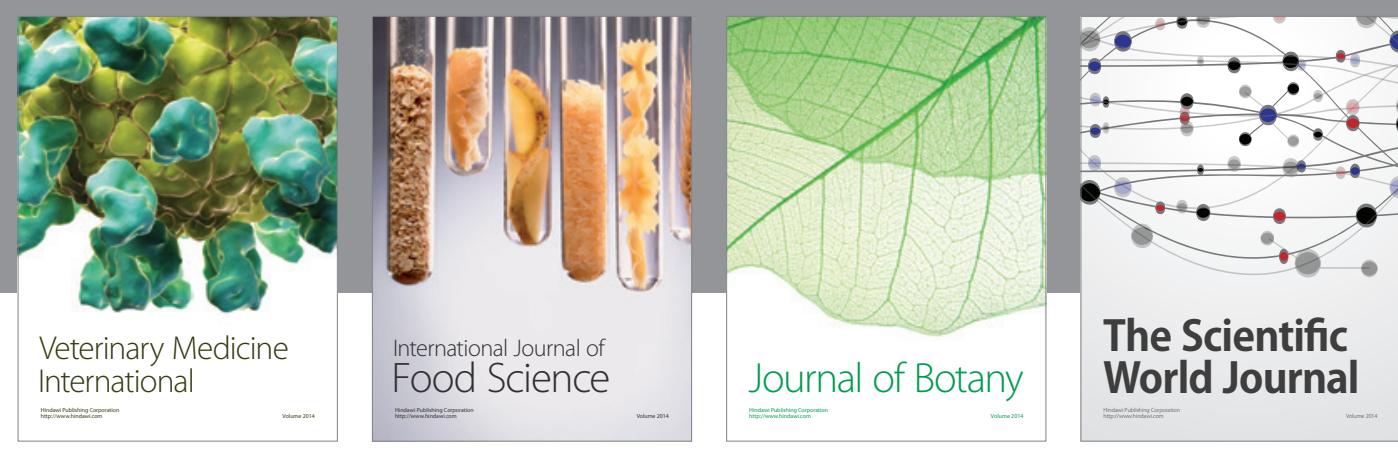

The Scientific

\section{World Journal}

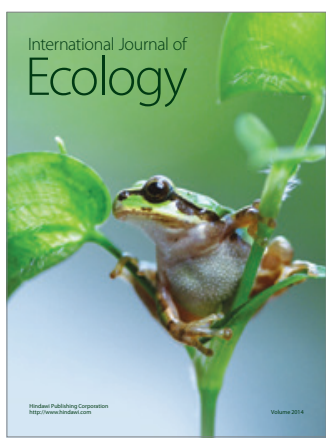

\section{Hindawi}

Submit your manuscripts at

https://www.hindawi.com
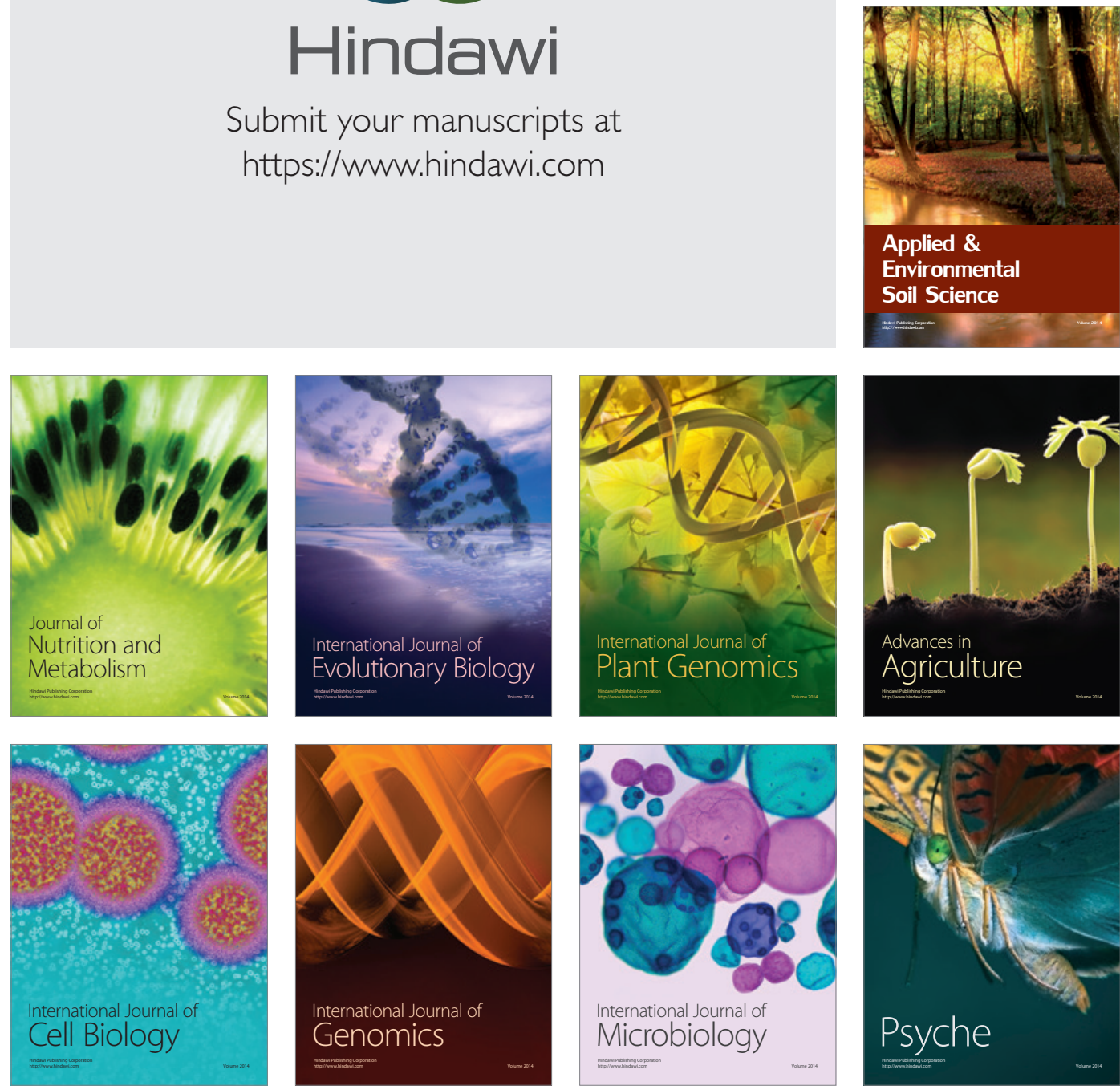
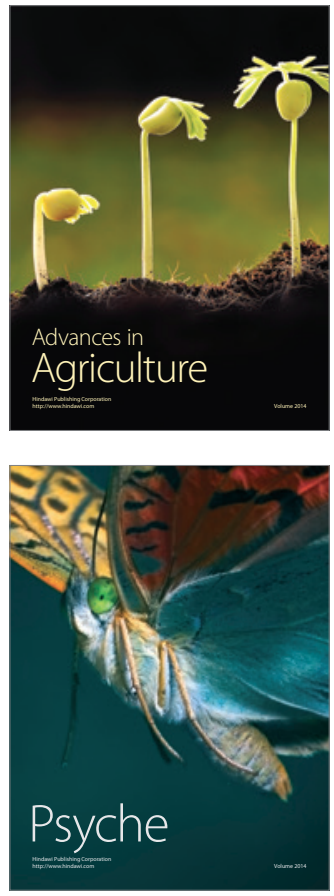